\title{
Review
}

Leigh-Anne Krometis*, Julia Gohlke, Korine Kolivras, Emily Satterwhite, Susan West Marmagas and Linsey C. Marr

\section{Environmental health disparities in the Central Appalachian region of the United States}

DOI 10.1515/reveh-2017-0012

Received March 27, 2017; accepted May 12, 2017; previously published online July 6, 2017

\begin{abstract}
Health disparities that cannot be fully explained by socio-behavioral factors persist in the Central Appalachian region of the United States. A review of available studies of environmental impacts on Appalachian health and analysis of recent public data indicates that while disparities exist, most studies of local environmental quality focus on the preservation of nonhuman biodiversity rather than on effects on human health. The limited public health studies available focus primarily on the impacts of coal mining and do not measure personal exposure, constraining the ability to identify causal relationships between environmental conditions and public health. Future efforts must engage community members in examining all potential sources of environmental health disparities to identify effective potential interventions.
\end{abstract}

Keywords: air quality; Central Appalachia; coal mining; environmental health; health disparities; rural health; water quality.

\section{Introduction}

Some of the most severe health disparities in the United States (US) occur in rural Appalachia, particularly in Central

\footnotetext{
*Corresponding author: Leigh-Anne Krometis, Biological Systems Engineering, Virginia Tech, 155 Ag Quad Lane, 312 Seitz Hall, Blacksburg, VA 24061-0303, USA, E-mail: krometis@vt.edu Julia Gohlke and Susan West Marmagas: Population Health Sciences, Virginia Tech, 205 Duck Pond Drive, Virginia Maryland College of Veterinary Medicine, Blacksburg, VA 24061-0395, USA Korine Kolivras: Geography, Virginia Tech, 220 Stanger St., 115 Major Williams Hall, Blacksburg, VA 24061, USA

Emily Satterwhite: Appalachian Studies, Religion and Culture, Virginia Tech, 280 Alumni Mall, 344 Lane Hall, Blacksburg, VA 24061, USA

Linsey C. Marr: Civil and Environmental Engineering, Virginia Tech, 1145 Perry St., Durham 411, Blacksburg, VA 24061, USA
}

Appalachia near the borders of Virginia, West Virginia, Kentucky and Tennessee. Not surprisingly, in all three of the strategic plans it has produced since 2002, the National Institute on Minority Health and Health Disparities has recognized Appalachia as an area exhibiting persistent disparities that require further research. A recent analysis of health disparities in this region posits that, "at least as measured by traditional epidemiologic variables", behavioral risk factors "seem insufficient to fully explain the region's health disparities" [1], and yet studies specifically targeting environmental health disparities in the region are limited.

In order to identify primary research needs and engagement strategies to better define and confront these disparities, this paper aims to: (1) review primary health disparities in the region and past attempts to link these disparities with the unique environmental and economic landscape of Central Appalachia; (2) discuss existing regional research on environmental quality, exposure and outcomes, with a specific focus on water and air; and (3) identify research needs and challenges.

\section{A history of health disparities}

As in other regions where there is intensive natural resource extraction, the Appalachian region is often described as subject to the "resource curse": poor economic conditions accompanying an abundance of minerals and fuels [2]. Historically, the region has been rich in natural resources such as timber, salt, gold, oil, iron ore, copper, and perhaps most notably, coal. Current land cover analysis indicates that, overall, $68 \%$ of the Central Appalachian region is forested, $27 \%$ is agricultural or pasture, $3 \%$ is developed (residential, commercial or industrial), $1 \%$ is wetlands or surface water and $1 \%$ is barren land, much of which is likely active mountaintop mining (Figure 1). Though barren land is small as an overall percentage, individual communities and counties can remain heavily impacted. Coal remains the source of one-third of electricity generation in the United States (US); however, production has sharply declined in the 


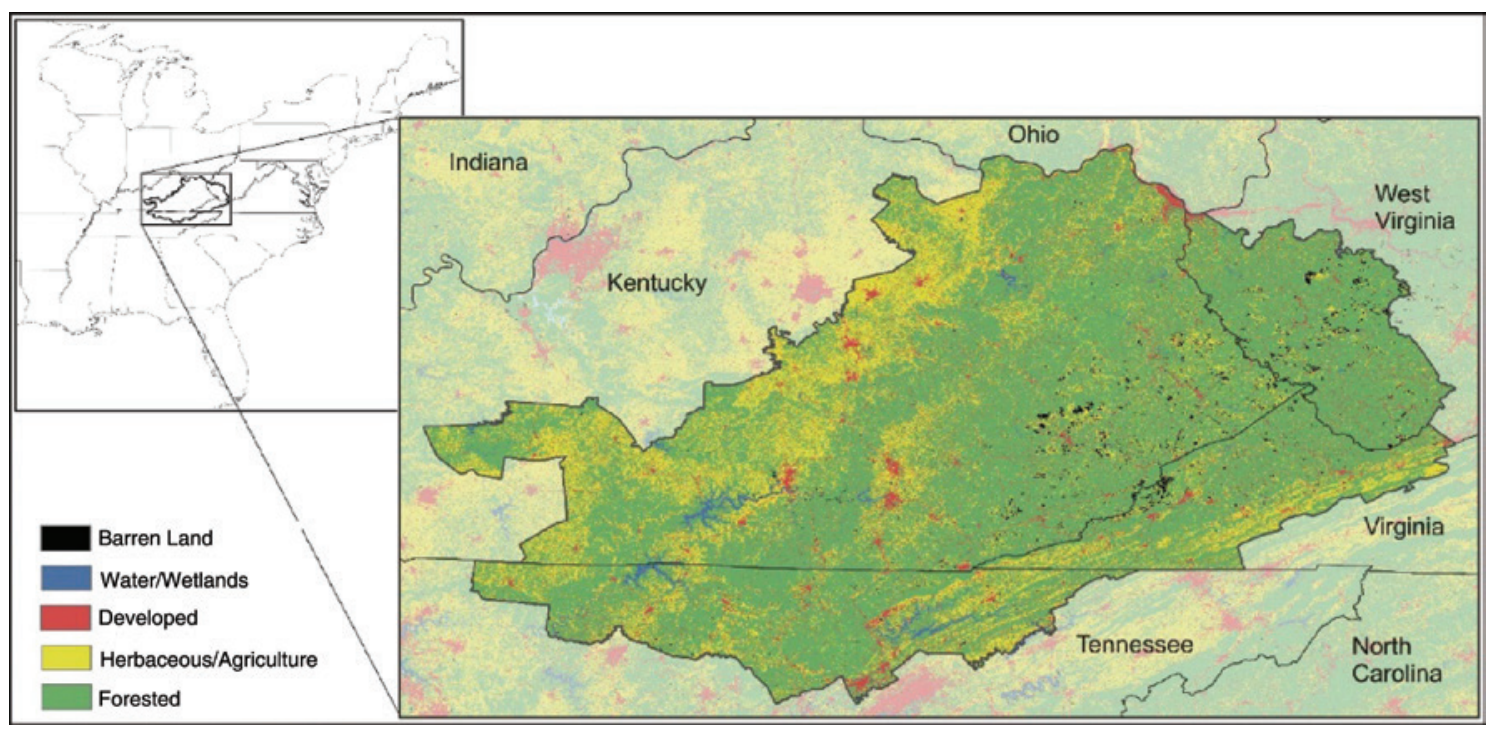

Figure 1: 2011 Land cover of the Central Appalachian region as currently defined by the Appalachian Regional Commission.

past decade as natural gas extraction in the region has become the predominant fossil fuel export [3, 4]. Despite this continuing trend, it is important not to discount coal's continuing impacts on the geography of Appalachia in the future: a recent geospatial model estimates that even under predictions of high natural gas production and low coal demand, almost $1000 \mathrm{~km}^{2}$ of new mine development is expected in Central Appalachia in the next 20 years [5].

Although health trends in Appalachia have not been extensively documented, concerns related to poor health status in mining regions were noted almost 40 years ago [6] and these concerns remain today $[7,8]$. Past studies indicate heightened incidences of chronic disease and premature mortality concentrated in Central Appalachia, with rates of cancer, cardiovascular and respiratory morbidity and mortality particularly elevated as compared to other regions of the US [9-14]. The most current available ageadjusted mortality data suggests these disparities are still present (Table 1). Note that, given the focus of this review on environmental risk factors rather than occupational risk factors, these data exclude the burden of disease associated with coal workers' pneumoconiosis ("black lung") and silicosis, which have been reviewed recently elsewhere [16].

Only a limited number of studies have been conducted to delineate the causes of observed health disparities, with the majority of research and outreach programs to date focused on lifestyle and behavioral risk factors. For example, obesity rates are particularly high in Appalachia; consequently, several cancer prevention programs have focused on increasing physical activity and promoting healthy eating, alongside increased screening initiatives in the broader region [17-19]. Reduced access to and utilization of health care remains a complicating issue in Appalachia that likely results in delayed diagnosis, suboptimal care, and ultimately worse outcomes from cancer, diabetes and cardiovascular and respiratory disease [20]. Most of rural Appalachia is designated as a health care shortage area (less than one primary care doctor per 3500 residents). Survey research indicates an overall poorer perception of health by communities in Appalachian counties versus non-Appalachian counties in the same states, and a need for low-cost health care services, particularly for dental, vision and mental health [21, 22]. Recently, Donohoe et al. [23] used a novel spatial accessto-care strategy incorporating driving time and distance to the nearest primary physician to demonstrate that residents in Appalachian counties have longer travel times to the nearest primary care doctor than residents in nonAppalachian counties in the same states.

In contrast to the comparatively thorough work related to socio-behavioral contributors to health in central Appalachia, for example, using standardized data collected through the Behavioral Risk Factor Surveillance System [24, 25], available investigations of environmental health disparities are very limited, and focus almost entirely on the impacts of coal mining, which remains both the dominant and the most regionally distinctive anthropogenic land-use. Ecological analyses have suggested county-level estimates of coal mining are a significant predictor of allcause and cause-specific county mortality after adjusting for sociodemographic characteristics [26-29]. However, a similar ecological analysis suggested that mortality rates were associated with county-level sociodemographic characteristics including poverty rate, median household 
Table 1: Mortality disparities in Central Appalachia (2010-2014).

\begin{tabular}{lrr}
\hline Health outcome $^{\text {a }}$ & $\begin{array}{r}\text { Rate per 100,000 in Central } \\
\text { Appalachiab (95\% Cl) }\end{array}$ & $\begin{array}{r}\text { Rate per 100,000 in } \\
\text { the US (95\% Cl) }\end{array}$ \\
\hline All mortality & $1040.6(987.4-1093.8)$ & $734.6(733.8-735.4)$ \\
All cancer mortality & $224.8(201.0-248.7)$ & $170.5(170.1-171.0)$ \\
Colorectal cancer mortality & $19.2(13.0-27.6)$ & $13.8(13.7-13.9)$ \\
Lung and bronchus cancer mortality & $79.0(65.4-93.6)$ & $44.6(44.4-44.8)$ \\
Heart disease mortality & $243.7(218.1-269.4)$ & $171.3(171.0-171.7)$ \\
COPD mortality & $74.1(60.6-88.7)$ & $37.8(37.6-38.0)$ \\
Demographics & Percent of population in & Percent of Population \\
& Central Appalachia & in the United States \\
\hline Age, \% $\geq 6$ years & 16.4 & 14.1 \\
Gender, \% female & 50.9 & 51.5 \\
Race and ethnicity, \% minority & 5.0 & 37.7 \\
Education, \% $\geq$ high school diploma & 76.6 & 86.7 \\
Living in poverty, \% & 24.4 & 15.5 \\
Health insurance, \% not covered & 13.0 & 13.0 \\
\hline
\end{tabular}

${ }^{a}$ Age-adjusted mortality data obtained from CDC WONDER database and includes data from 2010 to 2014. CDC (2012). Deaths: Leading Causes for 2008. National Vital Statistics Reports, 60(6), 3. Cause of death for all cancer (C00-D48), colorectal cancer (C18.0, C18.1, C18.2, C18.3, C18.4, C18.5, C18.6, C18.7, C18.8, C18.9, C20), lung and bronchus cancer (C34.0, C34.1, C34.2, C34.3, C34.8, C34.9), heart disease (I00-102, I11.0, I11.9, I13.0, I13.1, I13.2, I13.9, I20-25, I26-I28, I30-I51), COPD (J44.0, J44.1, J44.8, J44.9). bCentral Appalachia refers to the 82 counties spanning four states as defined by the Appalachian Regional Commission [Subregions in Appalachia - Appalachian Regional Commission (n.d.). Retrieved from http://www.arc.gov/research/MapsofAppalachia.asp?MAP_ID=31]. Colorectal cancer calculations are missing data from nine counties (Cumberland, KY; Lee, KY; Leslie, KY; Menifee, KY; Owsley, KY; Robertson, KY; Wolfe, KY; Hancock, TN; Pickett, TN). 'Demographic information retrieved from Pollard et al. [15], which compiled data from the US Census Bureau, 2011-2015 American Community Survey. Educational attainment is limited to population 25 years and over and gender is limited to civilian population ages 18 and over.

income, percent high school graduates and race/ethnicity, and that the level of coal mining in the county did not significantly improve model fits [1]. More recent studies of all-cause mortality rates in Appalachian counties found higher rates of cardiovascular deaths in coal counties compared to non-coal counties, even after adjustment for socioeconomic factors and obesity [30, 31]. A recent compendium of trends in sociodemographic data suggests Central Appalachians currently have similar health insurance rates compared to the population of the US as a whole, yet still have higher rates of poverty and lower rates of education (Table 1) [15].

A common complication in epidemiological examinations of environmental health effects in Appalachia is the particularly high smoking rate throughout the region [32], which likely accounts for a large portion of the observed disparity in cancers of the lung, head and neck [33]. Even so, regression models adjusting for county-level smoking rates suggest environmental exposures may also contribute to lung cancer disparities in coal mining counties of Appalachia [29]. A recent analysis in West Virginia used a pre/post study design to determine whether environmental exposures associated with mountaintop removal mining, which became prevalent in the 1980s, could have contributed to lung and bronchus cancer deaths in the 2006-2012 period as compared to the 1950-1969 time period [34].
Interestingly, after correcting for smoking rate and latency period, lung and bronchus cancer was significantly higher for residents in counties with the most mountaintop removal mining [smoking corrected odds ratio (OR): 1.39, 95\% confidence interval (CI) 1.37, 1.41], but there was not a significant association between coal mining occupation and lung cancer death, though this would be presumed to comprise the most exposed subpopulation.

Although heightened obesity rates found in Appalachia can partially explain disparities in cardiovascular disease (CVD), several studies indicate that, even after accounting for obesity rates and socioeconomic factors, deaths from CVD are positively associated with the amount of coal produced at the county level $[35,36]$, particularly in counties with mountaintop removal mining [37]. These findings are consistent with a wide and robust body of literature linking fine particulate matter smaller than $2.5 \mu \mathrm{m}$ $\left(\mathrm{PM}_{2.5}\right)$ exposure to cardiovascular toxicity, though it is worth nothing that the literature is primarily focused on $\mathrm{PM}_{2.5}$ and its constituents in urban environments [38].

\section{Potential sources of exposure}

Regulatorysystems that limit environmental contamination pollutant-by-pollutant and traditional discipline-specific 
research initiatives generally have not encouraged holistic cumulative measures of human exposure and outcomes [39]. This review therefore focuses on air and water exposures separately, while recognizing the likely interactions of multiple exposures on health outcomes. Although other sources of exposure (e.g. soil, food) may contribute to cumulative lifetime exposures, this review focuses on water and air, given their frequent mention as potential vectors for human exposure to contaminants in the region $[8,40,41]$. It is interesting to note the seeming discrepancy between the amount of past research focused on ecological health versus human health; for example, a search of ScienceDirect focused on aquatic ecology ("Appalachia" AND "water" AND "ecology") yields 216 publications, while a search focused on drinking water ("Appalachia" AND “drinking water" AND "human health") yields 35 publications. Similarly, a ScienceDirect search focused on the effects of air pollution on the nonhuman environment ("Appalachia” AND "air quality" AND "environment") yields 77 publications, while a search focused on air and human health ("Appalachia" AND "air quality" AND "human health") returns only 30 publications.

\section{Air quality}

Exposure to air pollution is associated with a range of adverse health effects, including premature mortality, lung cancer, chronic obstructive pulmonary disease, CVD, stroke, asthma, damage to the central nervous system and poor birth outcomes [42-47]. In general, Central Appalachia's trends in air quality mirror those of the broader US, although measurements at existing monitoring sites may not reflect the full spatial variability in pollutant concentrations in this topographically complex region. The U.S. Environmental Protection Agency (EPA) requires monitoring of "criteria" pollutants known to cause adverse health effects such as CVD and respiratory irritation. Figure 2 illustrates trends in $\mathrm{PM}_{2.5}$, coarse particulate matter smaller than $10 \mu \mathrm{m}$ in diameter $\left(\mathrm{PM}_{10}\right)$, ozone $\left(\mathrm{O}_{3}\right)$, sulfur dioxide $\left(\mathrm{SO}_{2}\right)$, nitrogen dioxide $\left(\mathrm{NO}_{2}\right)$ and carbon monoxide (CO) at monitoring sites in Central Appalachia. Pollutant concentrations at these monitoring sites have been similar in magnitude to the national average and have decreased over time in concert with the passing of stricter regulations, with the exception of ozone at Union, TN, and sulfur dioxide at Wayne, WV. Presently, concentrations of all pollutants at these sites are well below the National Ambient Air Quality Standards, with the exception of ozone; however, ozone levels at many sites in Central Appalachia remain close to the standard.
It is important to recognize that because the trends shown in Figure 2 are limited to the criteria pollutants at monitoring sites, which tend to be situated in more populous areas, they do not fully represent the state of air quality in Central Appalachia or all potential human exposures. There is evidence that the region is a significant outlier relative to the rest of the country in terms of acidic particles. In samples collected at 24 sites across the US in 1988-1991, the most acidic particles occurred in northern, north central and central Appalachia, where emissions of sulfur dioxide $\left(\mathrm{SO}_{2}\right)$ were highest; this is unsurprising as $\mathrm{SO}_{2}$ originates mainly from coal combustion, which is a major regional energy source [48]. Aneja et al. [49] measured residential exposure to $\mathrm{PM}_{10}$ at two sites for 2 weeks in 2008. The $\mathrm{PM}_{10}$ was largely generated by trucks hauling coal along roads navigating narrow valleys, known locally as "hollows". The mean $\mathrm{PM}_{10}$ concentrations at the two sites were $250 \mu \mathrm{g} \mathrm{m}^{-3}$ and $145 \mu \mathrm{g} \mathrm{m}^{-3}, 67 \%$ higher than and just under the National Ambient Air Quality Standard of $150 \mu \mathrm{g} \mathrm{m}^{-3}$, respectively. Kurth et al. [50] found that particle number concentrations were higher around coal mining sites than around non-mining sites. Some but not all $\mathrm{PM}_{2.5}$ and $\mathrm{PM}_{10}$ samples collected near surface mining sites were enriched in certain crustal elements ( $\mathrm{Ga}, \mathrm{Al}, \mathrm{Ge}$, $\mathrm{Rb}, \mathrm{La}, \mathrm{Ce}$ ) as compared to samples collected near underground mining sites or sites with no mining activity [51].

The most detailed air quality measurements in Appalachia come from two mountaintop research sites in North Carolina (Whitetop and Mt. Mitchell), which are in the south central portion of the region. Motivated by concern about damage to forests and crops [52, 53], studies at these sites have focused mainly on ozone and precipitation acidity, which is caused by emissions of $\mathrm{SO}_{2}$ and $\mathrm{NO}_{2}$. Implementation of the Clean Air Act Amendments in 1995 led to stricter limits on emissions and a substantial decrease in sulfur in cloud water and precipitation [5456]. Ozone concentrations were found to increase with elevation at Mt. Mitchell and, in contrast to diurnal patterns in urban areas, were highest at nighttime rather than daytime [57-59]. Therefore, people living at higher altitudes could be exposed to higher levels of ozone than predicted by lower-lying monitoring sites. Elemental analysis of particles collected at Whitetop showed that while $\mathrm{PM}_{2.5}$ was dominated by sulfur, larger particles also contained metals of crustal origin (e.g. Al, Ca, Fe, Si) [60], indicating windblown dust as a contributor to $\mathrm{PM}_{2.5^{\circ}}$

Most of the research on air quality in Central Appalachia has been driven by concerns over visibility, acid deposition, and damage to vegetation [52, 53, 61-66]. Between 1992 and 2002, the Southern Appalachian Mountains Initiative established a partnership of government, industry, 

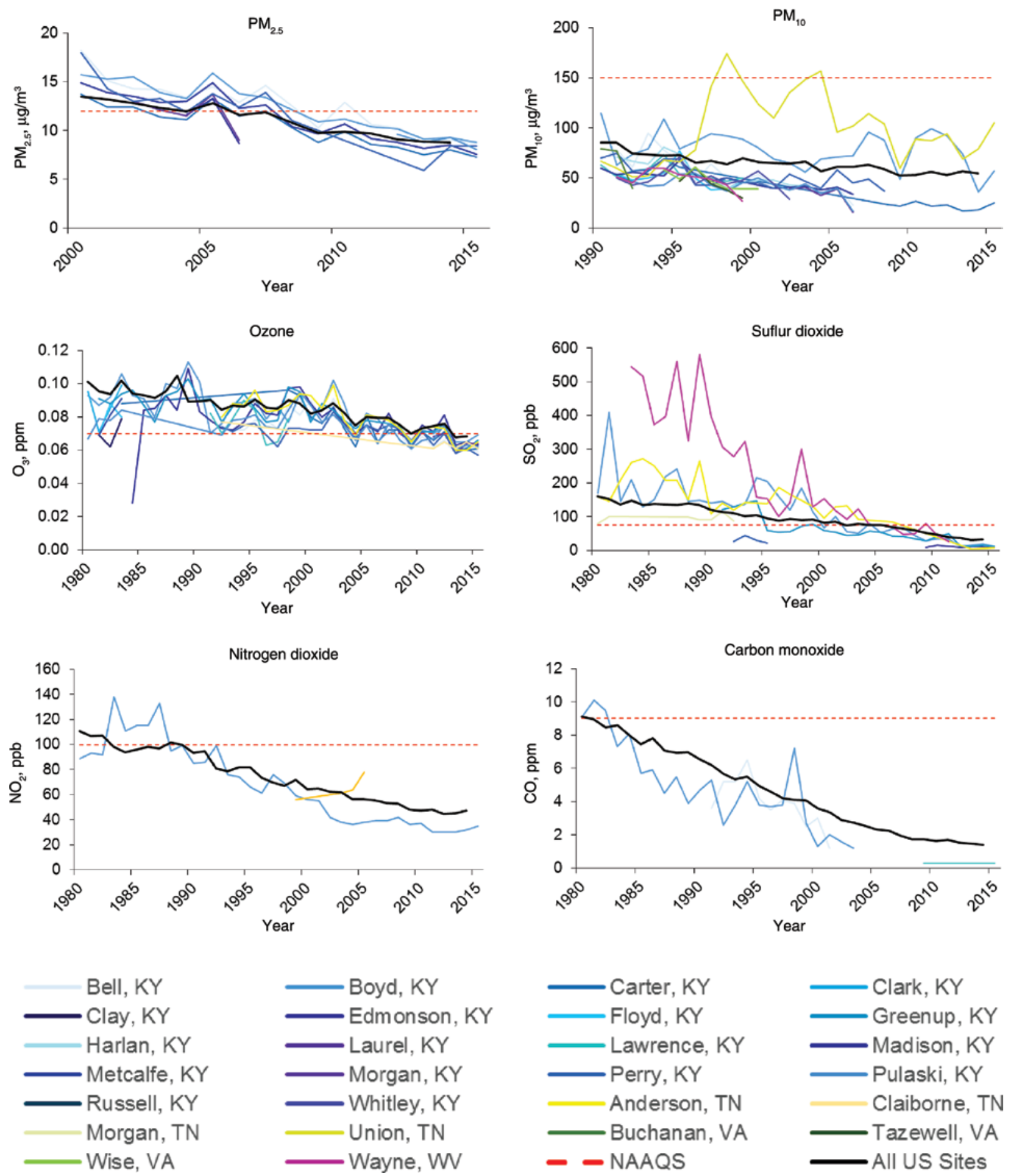

Figure 2: Air quality trends in counties in Central Appalachia compared to the average across all US sites and the National Ambient Air Quality Standard (NAAQS). Metrics are of the form specified by the NAAQS.

academia, and the public whose goal was to improve air quality, particularly visibility and ecosystem impacts, in national parks and wilderness areas in the southeastern US. As part of this initiative, sulfur-containing compounds and organic carbon were found to be the largest contributors to visibility degradation in the region [67-70]. One outcome of the initiative was new regulations on coalfired power plants in North Carolina, and in subsequent years, $\mathrm{SO}_{2}$ emissions decreased by $20.3 \%$ per year while $\mathrm{PM}_{2.5}$ sulfate concentrations decreased by $8.7 \%$ per year 
[71]. As a result, the risk of death associated with $\mathrm{PM}_{2.5}$ sulfate was estimated to decrease by $63 \%$, preventing 1700 deaths in 2012.

Only recently have studies begun to explicitly address potential links between air pollution exposure and human health in the region. Studies have found that intratracheal instillation in rats of $\mathrm{PM}_{10}$ collected near an active mountaintop removal mining site in West Virginia induced mitochondrially-driven apoptosis in heart tissue [72] and microvascular dysfunction [73]. The PM showed potentially carcinogenic effects on human lung cells, while control PM collected in a rural area with no mining activity, $160 \mathrm{~km}$ away, did not show these effects [74].

Considerable research is needed to expand the database of measurements and to provide proper controls to study the impact of mining versus other types of resource extraction and activities. Due to the complex topography of the region, there is likely to be high spatial variability in pollutant concentrations [75] that is not captured by the EPA's routine monitoring sites. Except for one study [49], there have been no measurements in hollows, where atmospheric inversions can trap pollutants and lead to localized high personal exposures for residents. It is possible that non-mining activity, such as construction or logging, could also lead to elevated PM concentrations and enrichment of certain species in the PM. The increased emphasis on natural gas extraction in the region may lead to new air quality concerns, as fracking fluids contain organic compounds that can escape into the atmosphere and aerated recycling ponds can be a source of air pollutant emissions [76]. Improving air quality in Central Appalachia may provide not just direct health benefits but also economic benefits, as the region is one of four areas in the US shown to have the greatest potential for "positive amenity values" of improved air quality [77].

\section{Water quality}

A survey in 2000 identified water quality as a primary environmental health concern of rural health care practitioners nationally [78]. Although no regionally specific data was presented for Central Appalachia, water contamination is frequently cited as a public health concern by Appalachian residents, as it provides a regular means of direct exposure to environmental contaminants [7, $40,79,80]$. Regional reliance on private drinking water systems (wells, springs, cisterns), which do not fall under the purview of the Safe Drinking Water Act's monitoring requirements, is significant. The Appalachian Regional
Commission currently estimates that only $75 \%$ of the region is served by municipal water systems [81], as compared to $85 \%$ nation-wide [82]. These private systems often do not employ treatment prior to consumption, which can leave households uniquely vulnerable to environmental contamination [83].

Despite its frequent mention as an environmental health concern, very little research is available on drinking water quality in Appalachia, and virtually no information regarding other waterborne exposures (e.g. recreational) is available. Available research is generally either linked to studies of coal mining impacts on community health, or, to a lesser extent, household sanitation and wastewater treatment. Much is based on perceptions or anecdotal data of water quality, with no direct measures of health impacts.

The potential that mining activities degrade drinking water sources and cause elevated rates of chronic disease has been recognized for decades. A review of historical environmental and community health concerns in Appalachia published in the late 1970s noted an elevated prevalence of gastrointestinal cancers (stomach, lip, mouth, throat) [6]. Though the author speculated that industrial contamination of drinking water might contribute to this prevalence, he also noted that elevated tobacco use in the region rendered the relative impacts of environmental contamination versus behavioral factors difficult to quantify. Similar observations of elevated rates of chronic diseases, particularly cancer, and speculation of a potential link to waterborne contaminants associated with mining practices is echoed by more recent reviews of community health concerns in Appalachia [8, 40]. However, these studies all rely on broad-scale analysis of secondary data sources (e.g. county-level cancer or vital statistics) and do not provide measures of water consumption (exposure) or contamination (dose) directly, rendering it difficult to identify a causal link.

A focus on water as a significant route of human exposure to contaminants associated with mining practices is not surprising given the substantial recent documentation of aquatic ecology impairments downstream of active or historical mining activity [7,84]. The exposure of mined overburden to oxygen and weather results in the discharge of metals and nonmetallic ions, generally measured as specific conductance, into Appalachian headwater streams. Elevated concentrations of ions are frequently cited as primarily responsible for losses in the abundance and diversity of aquatic benthic macro-invertebrates, which underlie aquatic food webs. Given the identification of Central Appalachia as a global biodiversity hotspot, the impacts of mining on water quality and hydro-ecology in 
the region have gained considerable scientific and public attention $[84,85]$.

Extrapolating the relative impacts of water quality on non-human versus human animals is inherently very difficult however, particularly in sensitive ecologies; for example, although the Safe Drinking Water Act maximum contaminant level for selenium in human drinking water is $50 \mathrm{ppb}$, recent studies in Central Appalachia suggest that levels as low as $5 \mathrm{ppb}$ can negatively impact local fish species [86]. Attempts to directly link degradation of invertebrate health directly with human health are difficult and controversial. A recent effort by Hitt and Hendryx [87] found a positive correlation between average stream health scores (WV Stream Condition Indices, or WVSCI) and the incidence of digestive, breast, respiratory and urinary cancer rates at the county level in West Virginia. The authors do not posit exposure pathways or common biological mechanisms that impact human cancers and macroinvertebrate extirpation, stating that "it is intuitive that ecological integrity and human health are intrinsically linked". It is worth noting that in this study, poverty, smoking and urbanization were examined in parallel via logistic regression and were also linked with elevated cancer rates (i.e. included in the model).

In contrast to the considerable in-stream water quality data available linking coal mining and ecological health, very little data is available on the quality of residents' drinking water, though several studies focus on community perceptions of water quality. Interviews with over 122 residents of Letcher County, Kentucky, revealed that residents' concerns regarding the perceived poor aesthetic quality and health risks of their water forced them to change their behavior, e.g. purchasing bottled water, cooking with water from a relative's home supplied by municipal water or washing clothes at a laundromat [80]. It is important to note that this study targeted residents who had expressed concerns related to their water previously; interviewees were not selected randomly. In addition, the study did not analyze any water samples, and although several residents expressed a belief that local coal mining had contributed to degraded water quality, some residents reported characteristics (e.g. iron staining) that may simply be the result of local geology. A targeted study in Mingo and Wyoming Counties in West Virginia similarly reported that perceptions of poor water quality and issue saliency (i.e. perception of problem seriousness) were the primary factors influencing households to purchase bottled water, even when this purchase represented a nontrivial portion of the family budget [79]. This effort recruited its 276 participants randomly by approaching every 12 th home on county roads, but similarly to the
Kentucky study, did not analyze actual water samples for markers of contamination. Interestingly, the West Virginia study found decisions to purchase bottled water appeared similar regardless of water source (private well or spring vs. municipal water); a lack of trust in the public water authority was cited as a common reason to purchase bottled water.

Only three studies reporting actual measures of household drinking water quality at the point of use in Appalachia were identified, all of which were constrained by small sample sizes or limited analytical strategies. Wigginton et al. [88] investigated the relative quantities of metals in household hot water tanks in Martin, Pulaski, and Madison Counties in Kentucky after the 2000 Martin County coal impoundment failure contaminated the county's surface water supply. Although the authors hypothesized that metals accumulation in the hot water tanks would be significantly higher in Martin County, concentrations were actually highest in Pulaski County homes, particularly for lead. This may be the result of underlying natural water chemistry, although neither $\mathrm{pH}$ nor alkalinity, considered primary drivers of corrosion and metal release, were reported. In addition, concentrations of metals at the household point of use, a more likely proxy for resident exposure, were not correlated with hot water tank values. In 2005, students in a service-learning course at Kentucky Community and Technical College collected 179 well water samples from personal and community contacts in Kentucky, West Virginia, Tennessee and Ohio to test for arsenic. Over half of the samples contained detectable arsenic levels, and ten samples (6\%) exceeded the Safe Drinking Water Act standard of 10 ppb [89]. A study comparing differences in water quality in samples collected from the point of use of private drinking water supplies participating in a Cooperative Extension program across Virginia found that the number of samples positive for fecal indicator bacteria were highest in samples from wells and springs in the Valley and Ridge geological region of Virginia (where multiple counties designated as Central Appalachian are located); roughly $50 \%$ of the 926 samples submitted from this region were positive for total coliform. The number of samples submitted from the Appalachian Plateau geological region was too small to warrant inclusion in the analysis [90].

A significant incidence of bacterial contamination in drinking water wells is not necessarily surprising, given continuing struggles to provide safe drinking water and adequate wastewater treatment in the region. A state-level analysis of the most recently available full 2000 Census on housing indicated that over 7000 homes in West Virginia, over 19,000 homes in Virginia, and almost 15,000 homes 

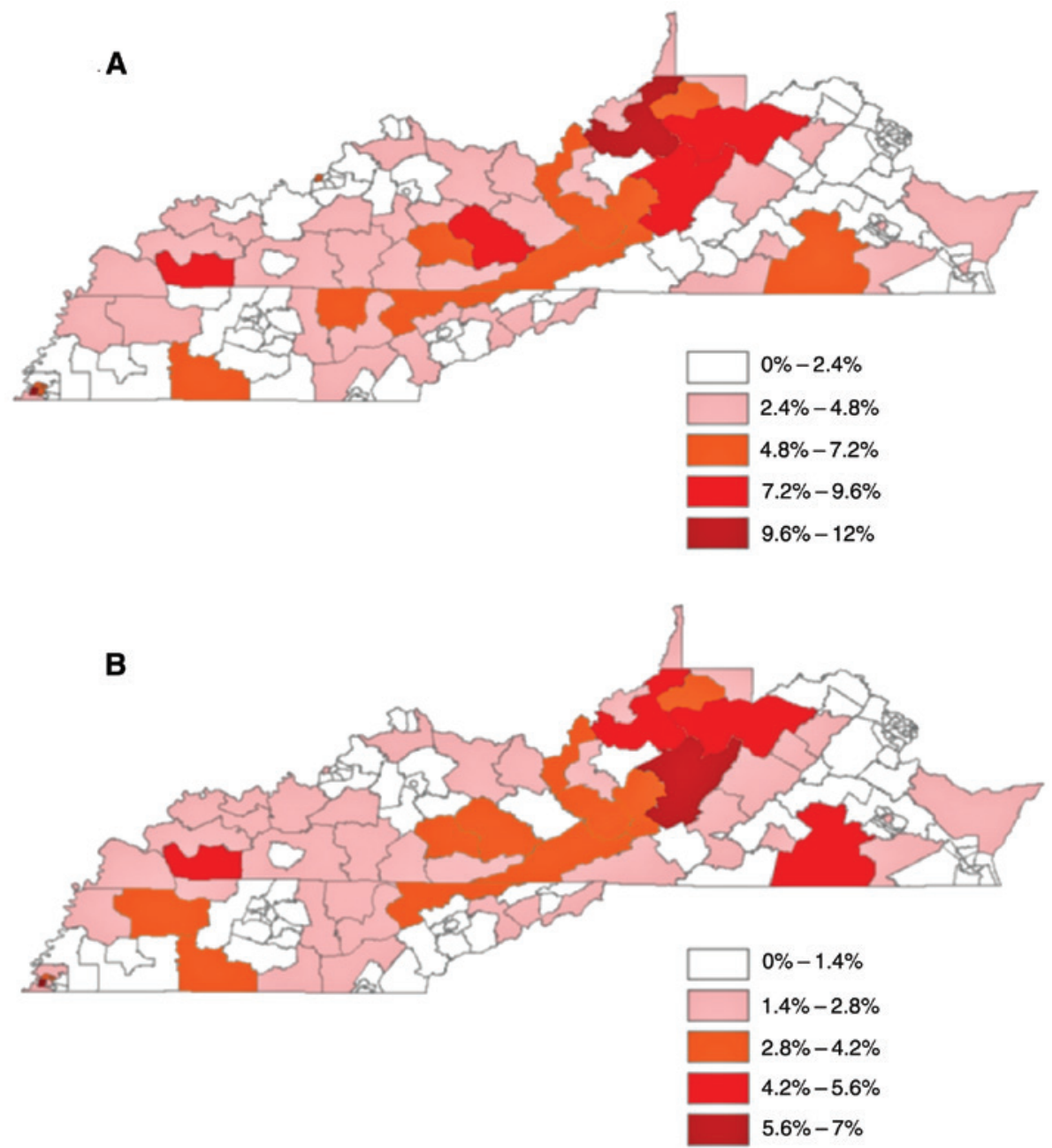

Figure 3: Percentage of occupied homes in Central Appalachian states: (A) without indoor plumbing (drinking water tap); and (B) without an indoor toilet. Data are compiled by United States' Census Bureau's Public Use Microdata Areas (PUMAs) using the 5 year 2010-2014 dataset (https://www.census.gov/programs-surveys/acs/data/pums.html). PUMAs are geographically defined by the US Census to include populations of 100,000 people. Homes are selected for detailed surveying via statistical methods designed to maximize representation of the entire PUMA population.

in Kentucky did not have indoor plumbing as of 2000 [91]. According to this analysis, West Virginia and Kentucky had the fourth and fifth greatest percentage of their overall population lacking these basic services, with $1.01 \%$ and $0.94 \%$ of household lacking indoor plumbing. Analysis of the more recent US Census Public Use Microdata System confirms that there are portions of Central Appalachian states where more than $10 \%$ of homes do not have indoor drinking water, and more than $7 \%$ of homes do not have an indoor toilet (Figure 3).

Not included in summaries of indoor plumbing availability are homes with flush toilets but inadequate wastewater treatment infrastructure. Narrow valleys and thin topsoil layers render traditional septic systems impractical for some locales; consequently, in the absence of municipal wastewater service or other affordable alternatives, some homes simply "straight pipe" household wastewater to nearby streams, i.e. untreated household wastewater passes directly into adjacent ditches and surface waterways [92, 93]. As straight pipes are technically illegal, this practice is difficult to quantify, although a report on environmental quality in Letcher County, Kentucky, estimated that as many as 3000 straight pipes serve up to 12,000 county residents [94]. Quantifying the number and location of straight pipes, as well as failing septic systems, is essential to understanding the risk to residents; a recent national study identified failing onsite wastewater as the primary risk factor in predicting gastroenteritis outbreaks in homes reliant on private wells [95]. 


\section{Future research suggestions}

The ecological impacts of environmental contaminants and anthropogenic land use in Central Appalachia have been relatively well studied. This is not necessarily surprising, given that the central and southern Appalachians are designated as an ecological biodiversity "hotspot" that hosts nearly 10,000 distinct species [96, 97]. Over the past several decades, recognition of the unique biodiversity of the region has prompted research into the effects of acid rain and air pollution on forests and the link between mineland discharges and the degradation of aquatic macro-invertebrates; these efforts have spurred concurrent regulatory efforts to reduce pollutant discharges and remediate these critical habitats. In contrast, the effects of the region's natural and human landscape changes on human health remain relatively unclear. Although Appalachia has long been recognized as an American region subject to significant health disparities, the causes of excess morbidity and mortality are poorly understood, limiting the design and implementation of interventions to improve public health. There are several lines of inquiry that warrant further research investigations, including:

\section{Individual, longitudinal measures of exposures for air and water and health outcomes}

The majority of past examinations of potential environmental contributions to health disparities in Appalachia have focused solely on the potential impacts of coal mining, generally at the county-level. While compelling in their calls for further research, conclusions from these studies are limited by their ecological study design. Individual-level exposures and their relationships to covariates are not measured in these studies, and the studies fail to account for latency periods between risk factors and health outcomes through the collection of longitudinal measures. Without individual, longitudinal measures of exposures and disease initiation and progression, associations between exposures and outcomes are difficult to identify. Moving forward, researchers must focus on obtaining measurements of individual exposure to specific pollutants in air and water, keeping in mind topographically influenced variability and proximity to resource extraction as well as additional sources of environmental pollution when selecting the sample population. Such measurements could include personal exposure to $\mathrm{PM}_{2.5}$ and specific metals and organic compounds in indoor (home) and outdoor air, and microbes, salts, metals, and organic compounds in drinking water collected at the point of exposure (e.g. the kitchen tap) in homes. In addition, while the presence of coal mining as a significant potential environmental risk cannot be ignored, additional environmental factors and patterns of land-use and land-use change must be examined as likely contributors to elevated regional burdens of disease.

\section{Health effects of natural gas extraction}

While coal production in the region has declined over the past decade, natural gas extraction, made more accessible by hydraulic fracturing or "fracking", has grown sharply. Increases in fracking immediately spurred a host of new concerns about its potential impacts on the environment, especially in terms of groundwater contamination $[3,4$, 98]. The associated human health impacts remain at times difficult to quantify [99], but it is worth noting that recent studies have observed increases in asthma [100], sinus headaches and fatigue [101], hospital visits [102], mental distress [103], and adverse birth outcomes [104, 105] near unconventional gas sites. Although the types of pollutants potentially released to the air, water, and soil by fracking operations and the pathways of human exposure likely differ from coal mining operations, regional experience with coal mining impacts must inform the development of monitoring strategies that can reliably inform policy and engage local communities. For example, the current growth in natural gas extraction by hydraulic fracturing presents an immediate opportunity for longitudinal studies of its community health effects that include direct measures of individual exposure. These effects must be distinguished from the impacts of conventional gas wells, which have not previously been explicitly studied.

\section{Health effects of changes in land use}

Understanding patterns of land-use, particularly landuse visible or in close proximity to human populations, is critical in understanding not only human health risks, but also community perceptions of risk and well-being. A recent focus group study of Appalachian women found that those who lived closest to new natural gas extraction wells reported greater feelings of powerlessness and attributed increased community illness to the industry's presence, while those who lived farther away did not believe the wells were responsible for poor health outcomes [106]. These links between awareness of landscape changes and perceived links to health are critical 
to recognize in working with Appalachian residents, and community concerns are reflected by the numerous water quality perception studies surrounding coal mining discussed previously. The shift to mountaintop removal mining in recent decades has introduced more extensive and distinctly visible environmental concerns, which likely impacts perceptions of risk, though this has been only lightly examined.

Impacts of land use and land cover change are most clearly revealed through the use of fine-scale satellite imagery and remote sensing techniques. Environmental change in Appalachia has been studied using such techniques, but the focus is typically on impacts on ecosystem health rather than human health [107-109]. There has been little attention focused on human health impacts of changing land use and land cover patterns through time in Central Appalachia, and many of the studies identified in this paper have conducted analyses at a relatively coarse county-scale. In order to truly tease apart the relationship between land cover change and human health impacts, fine-scale data should be employed. Individuallevel address-based health outcomes and exposure measures related to air and water quality should be paired with fine-scale satellite imagery using a geographic information system (GIS) to understand links between land cover change and human health, and to reveal the potential for interventions and improvements to health outcomes.

\section{Mental health considerations}

There are anecdotal reports of depression and associated issues in communities near mountaintop removal mines. For example, Cordial et al. report that "virtually no research has been undertaken on the psychological effects of" mountaintop removal mining but hypothesize "a high probability of an increased risk of mental health problems for those living near MTR sites” [110]. The Appalachian Regional Commission has found that "persons in Central Appalachia, where coal mining is heaviest, are at greater risk for major depression and severe psychological distress compared with other areas of Appalachia or the nation" [111]. The only available studies of community mental health and well-being are ecologically-based studies focused on the county-level, which, as mentioned previously, do not record individual-level exposures or covariates, rendering causal relationships difficult to determine [112]. The term "solastalgia" is used to describe mental distress following landscape changes, especially when these environmental changes occur in the person's home environment. Future studies building on the emerging literature and investigative strategies associated with explorations of solastalgia and other psychoterratic syndromes [113] are encouraged to test the hypothesis that Appalachian communities near extractive industries suffer from mental health effects. It is important to note when designing these studies that changes in the environment that result in emotional distress do not necessarily only comprise dramatic landscape shifts on the scale of mountaintop removal; recent work suggests that fracking, despite its lower visible environmental footprint, is also associated with shifts in individual sense of place, identity and community [103].

\section{Conclusion: building community through participatory research}

As research efforts to characterize the impacts of environmental changes in Appalachian communities develop, parallel efforts to educate and involve targeted communities should draw from evidence-based practice on community engagement and community-based participatory research. Successful interventions to reduce environmental health disparities require processes "whereby communities use their voice to define and make health concerns known" [114], as well as community capacity building [115]. This process can redress communities' sense of disenfranchisement, strengthen opportunities for community voices to influence research priorities, policy and health education, increase community trust in research findings and embolden residents' perceived self-efficacy in effecting change. For example, Hutson et al. established community research review work groups to engage community leaders in a series of focus groups to disseminate information about cancer disparities and build relationships with healthcare providers [116].

Existing evidence-based models in Appalachia to address social and behavioral factors associated with regional health disparities are evident in the interventions by researchers with the Appalachian Community Cancer Network and others, and can be leveraged for future community engagement to address environmental health disparities, particularly in vulnerable populations such as children and the elderly [14, 117]. For example, implementation of the American Cancer Society's “Tell a Friend" program in local food pantries in an Appalachia community in Pennsylvania resulted in a $28 \%$ increase in breast cancer screenings [118]. Implementation of the "Winning With Wellness" obesity prevention initiative in elementary schools resulted in increases in daily steps and 
healthier food selections by students even 4 years later. Building from these successful programs, environmental health modules could be developed and validated for school-based or community organization programs [119]. Ultimately, working with communities will foster interdisciplinary research, bringing together disparate disciplines (e.g. public health, geography, ecology, natural resources management, etc.) to help solve problems identified by impacted Appalachia communities.

Appalachia is frequently described as a region with communities highly tied to the idea of "place" [120-122]. Although current health and economic challenges are significant, residents' dedication to the mountains may serve as a source of strength and cohesion for addressing environmental health issues. Given the rich history and beauty of Appalachia, there are opportunities for residents of the region to leverage the environment to reinvigorate communities, promote regional health, and preserve and/or reinscribe sense of place for future generations.

Acknowledgments: We thank Katherine Williams, Urban Withers and Archit Manuja for assistance with data gathering and figure preparation.

\section{Author Statement}

Research funding: Funding for this research was provided by the Virginia Tech Institute for Society, Culture, and Environment; the Virginia Tech Global Change Center; and the Institute for Critical Technology and Applied Science at Virginia Tech. Conflict of interest: Authors state no conflict of interest. Informed consent: Informed consent is not applicable. Ethical approval: The conducted research is not related to either human or animals use.

\section{References}

1. Borak J, Salipante-Zaidel C, Slade MD, Fields CA. Mortality disparities in Appalachia: reassessment of major risk factors. J Occup Environ Med 2012;54(2):146-56.

2. Douglas $S$, Walker A. Coal mining and the resource curse in the eastern United States. J Reg Sci 2016; DOI: 10.1111/jors.12310.

3. Finkel ML, Law A. The rush to drill for natural gas: a public health cautionary tale. Am J Public Health 2011;101(5):784-5.

4. Vidic RD, Brantley SL, Vandenbossche JM, Yoxtheimer D, Abad JD. Impact of shale gas development on regional water quality. Science 2013;340:826-35.

5. Strager MP, Strager JM, Evans JS, Dunscomb JK, Kreps BJ, et al. Combining a spatial model and demand forecasts to map future surface coal mining in Appalachia. PLoS One 2015;10(6):e0128813.

6. Guidotti TL. Health implications of increased coal use in the Western states. West J Med 1979;131(1):70-6.
7. Holzman DC. Mountaintop removal mining: digging into community health concerns. Environ Health Perspect 2011;119(11):A476-83.

8. Hendryx M. The public health impacts of surface coal mining. Extr Ind Soc 2015;2(4):820-6.

9. Barnett E, Halverson J, Elmes G, Braham V. Metropolitan and nonmetropolitan trends in coronary heart disease mortality within Appalachia, 1980-1997. Ann Epidemiol 2000;10(6):370-9.

10. Halverson JA, Harner EJ. An analysis of disparities in health status and access to health care in the Appalachian region. 2004. [Online]. Available at: https://www.arc.gov/research/ researchreportdetails.asp?REPORT_ID=82.

11. Halverson JA, Barnett E, Casper M. Geographic disaprities in heart disease and stroke mortality among black and white populations in the Appalachian region. Ethn Dis 2002;12(4):91.

12. Blackley D, Behringer B, Zheng S. Cancer mortality rates in Appalachia: descriptive epidemiology and an approach to explaining differences in outcomes. J Community Health 2012;37(4):804-13.

13. Gatz JL, Rowles GD, Tyas SL. Health disparities in rural Appalachia. In: Glasgow N, Wright L, Johnson N, editors. Critical issues in rural health. Hoboken, NJ, USA: Wiley-Blackwell, 2004.

14. Paskett ED, Fisher JL, Lengerich EJ, Schoenberg NE, Kennedy SK, et al. Disparities in underserved white populations: the case of cancer-related disparities in Appalachia. Oncologist 2011;16(8):1072-81.

15. Pollard K, Jacobsen LA. The Appalachian region: a data overview from the 2011-2015 American Community Survey," 2017. [Online]. Available at: https://www.arc.gov/assets/research_reports/DataOverviewfrom2011to2015ACS.pdf. Accessed: 25-Apr-2017.

16. Arnold C. A scourge returns: black lung in Appalachia. Environ Health Perspect 2016;124(1):a13-8.

17. Baltic RD, Weier RC, Katz ML, Kennedy SK, Lengerich EJ, et al. Study design, intervention, and baseline characteristics of a group randomized trial involving a faith-based healthy eating and physical activity intervention (Walk by Faith) to reduce weight and cancer risk among overweight and obese Appalachian adults. Contemp Clin Trials 2015;44:1-10.

18. Fisher JL, Engelhardt HL, Stephens JA, Smith BR, Haydu GG. Cancer-related disparities among residents of Appalachia Ohio. J Health Dispar Res Pract 2008;2(2):4.

19. Kluhsman BC, Bencivenga M, Ward AJ, Lehman E, Lengerich EJ. Initiatives of 11 Rural Appalachian cancer coalitions in pennsylvania and New York. Prev Chronic Dis 2006;3(4):A122.

20. Lane N, Konrad R, Ricketts T. Health care costs and access disparities in Appalachia. Available at: http://www.arc.gov/assets/ research_reports/healthcarecostsandaccessdisparitiesinappalachia.pdf, 2012.

21. Mcgarvey EL, Maguadalupe L-V, Killos LF, Guterbock T, Cohn WF. Health disparities between Appalachian and non-Appalachian counties in Virginia USA. J Community Health 2011;36(3):348-56.

22. Huttlinger K, Schaller-Ayers J, Lawson T. Health care in appalachia: a population-based approach. Public Health Nursing 2004;21(2):103-10.

23. Donohoe J, Marshall V, Tan X, Camacho FT, Anderson R, et al. spatial access to primary care providers in Appalachia evaluating current methodology. J Prim Care Community Health 2016:7(3):149-58.

24. Barker L, Crespo R, Gerzoff R, Denham S, Shrewsberry M, et al. Residence in a distressed county in Appalachia as a risk factor for diabetes, behavioral risk factor surveillance system, 2006-2007. Prev Chronic Dis 2010;7(5):A104. 
25. Sohn M-W, Kang H, Park JS, Yates P, McCall A, et al. Disparities in recommended preventive care usage among persons living with diabetes in the Appalachian region. BMJ Open Diabetes Res Care 2016;4(1):e000284.

26. Hendryx M, Ahern MM. Mortality in Appalachian coal mining regions: the value of statistical life lost. Res Artic Public Heal Reports 2009;124(4):541-50.

27. Hendryx M, Ahern M. Reply to Borak et al mortality disparities in Appalachia: reassessment of major risk factors. J Occup Environ Med 2012;54(7):768-9.

28. Hendryx M. Mortality from heart, respiratory, and kidney disease in coal mining areas of Appalachia. Int Arch Occup Environ Health 2009;82:243-9.

29. Hendryx M, O’Donnell K, Horn K. Lung cancer mortality is elevated in coal-mining areas of Appalachia. Lung Cancer 2008;62(1):1-7.

30. Woolley SM, Meacham SL, Balmert LC, Talbott EO, Buchanich JM. Comparison of mortality disparities in central Appalachian coal-and non-coal-mining counties. J Occup Environ Med 2015;57(6):687-94.

31. Buchanich JM, Balmert LC, Youk AO, Woolley SM, Talbott EO. General mortality patterns in Appalachian coal-mining and non-coal-mining counties. J Occup Environ Med 2014;56(11):1169-78.

32. Meyer MG, Toborg MA, Denham SA, Mande MJ. Cultural perspectives concerning adolescent use of tobacco and alcohol in the Appalachian mountain region. J Rural Heal 2008;24(1):67-74.

33. Wingo PA, Tucker TC, Jamison PM, Martin H, McLaughlin C, et al. Cancer in Appalachia, 2001-2003. Cancer 2008;112(1):181-92.

34. Crosby L, Tatu C, and Charles K. Lung and bronchus cancer deaths in Boone County, Wv before and after mountaintop removal mining. Journal of Rare Disorders: Diagnosis and Therapy 2016;2(1):1-8.

35. Woolley SM, Youk AO, Bear TM, Balmert LC, Talbott EO, et al. Impact of coal mining on self-rated health among Appalachian residents. J Environ Public Health 2015. http://dx.doi. org/10.1155/2015/501837.

36. Balmert L, Youk AO, Woolley S, Talbott E, Buchanich JM. Heart Disease Mortality in Appalachian Coal Mining Counties. SM J Public Heal Epidemiol 2015;1(1):1002.

37. Esch L, Hendryx M. Chronic cardiovascular disease mortality in mountaintop mining areas of central Appalachian states. J Rural Health 2011;27(4):350-7.

38. Simkhovich BZ, Kleinman MT, Kloner RA. Air pollution and cardiovascular injury: epidemiology, toxicology, and mechanisms. J Am Coll Cardiol 2008;52(9):719-26.

39. Scammell MK, Montague P, Raffensperger C. Tools for addressing cumulative impacts on human health and the environment. Environ Justice 2014;7(4):102-9.

40. Hendryx M. Health and the physical environment. In: Ludke RL, Obermiller PJ, editors. Appalachian health and well-being. Lexington, KY, USA: University Press of Kentucky, 2012:47-66.

41. Christian WJ, Huang B, Rinehart J, Hopenhayn C. Exploring geographic variation in lung cancer incidence in Kentucky using a spatial scan statistic: elevated risk in the Appalachian coal-mining region. Res Artic Public Heal Reports 2011;126(6):789-96.

42. Hoek G, Krishnan RM, Beelen R, Peters A, Ostro B, et al. Longterm air pollution exposure and cardio- respiratory mortality: a review. Environ Health 2013;12(1):43.

43. Guarnieri M, Balmes JR, Francisco S. Outdoor pollution and asthma. HHS Public Access 2014;383(9928):1581-92.
44. Block ML, Elder A, Auten RL, Bilbo SD, Chen H, et al. Neurotoxicology the outdoor air pollution and brain health workshop. Neurotoxicology 2012;33(5):972-84.

45. Clifford A, Lang L, Chen R, Anstey KJ, Seaton A. Exposure to air pollution and cognitive functioning across the life course - A systematic literature review. Environ Res 2016;147:383-98.

46. Gray SC, Edwards SE, Schultz BD, Miranda ML. Assessing the impact of race, social factors and air pollution on birth outcomes: a population-based study. Environ Health 2014;13(4). DOI: 10.1186/1476-069X-13-4.

47. Dadvand P, Parker J, Bell ML, Bonzini M, Brauer M. Research children's health maternal exposure to particulate air pollution and term birth weight: a multi-country evaluation of effect and heterogeneity. Environ Health Perspect 2013;121(3):367-73.

48. Spengler JD, Koutrakis P, Dockery DW, Raizenne M, Speizer FE. Health effects of acid aerosols on north American children: air pollution exposures. Environ Health Perspect 1996;104(5):492-9.

49. Aneja VP, Isherwood A, Morgan P. Characterization of particulate matter (PM10) related to surface coal mining operations in Appalachia. Atmos Environ 2012;54:496-501.

50. Kurth LM, McCawley M, Hendryx M, Lusk S. Atmospheric particulate matter size distribution and concentration in West Virginia coal mining and non-mining areas. J Expo Sci Environ Epidemiol 2014;24(4):405-11.

51. Kurth L, Kolker A, Engle M, Geboy N, Hendryx M, et al. Atmospheric particulate matter in proximity to mountaintop coal mines: sources and potential environmental and human health impacts. Environ Geochem Health 2015;37(3):529-44.

52. Anderson RL, Chevone BI, Chappelka AH, Brown HD. Occurence of air-pollution symptoms on eastern white pine in the Southern Appalachian Mountains. Phytopathology 1986;76(10):1084-5.

53. Aneja VP, Robarge WP, Claiborn CS, Murthy A, Soo-Kim D, et al. Chemical climatology of high elevation spruce fir forests in the Southern Appalachian Mountains. Environ Pollut 1992;75(1):89-96.

54. Lynch JA, Bowersox VC, Grimm JW. Changes in sulfate deposition in eastern USA following implementation of phase I of title IV of the clean air act amendments of 1990. Atmos Environ 2000;34(11):1665-80.

55. Mueller SF. Ambient sulfate trends and the influence of meteorology. J Appl Meteorol 2005;44(11):1745-60.

56. Anderson JB, Baumgardner RE Jr, Grenville SE. Trends in cloud water sulfate and nitrate as measured at two mountain sites in the eastern United States: regional contributions and temporal changes compared with regional changes in emissions, 1986-1999. Atmos Environ 2006;40(23):4423-37.

57. Aneja VP, Claiborn CS, Li Z, Murthy A. Trends, seasonal variations, and analysis of high-elevated surface nitric acid, ozone, and hydrogen peroxide. Atmos Environ 1994;28(10):1781-90.

58. Aneja VP, Businger S, Li Z, Claiborn CS, Murthy A. Ozone climatology at high elevations in the Southern Appalachians. J Geophys Res 1991;96(D1):1007-21.

59. Zaveri RA, Saylor RD, Peters LK, McNider R, Song A. A model investigation of sumertime diurnal ozone behavior in rural mountainous locations. Atmos Environ 1995;29(9):1043-65.

60. Reisinger LM. Analysis of airborne particles sample in the Southern Appalachian mountains. Water Air Soil Pollut 1990;50(1-2):149-62. 
61. Lefohn AS, Lucier AA. Spatial and temporal variability of ozone exposure in firested areas of the United States and Canada, 1978-1988. J Air Waste Manage Assoc 1991;41(5):694-701.

62. Shaver CL, Tonnessen KA, Maniero TG. Clearing the air at great smoky mountains national park. Ecol Appl 1994;4(4):690-701.

63. Peine JD, Randolph JC, Presswood JJ. Evaluating the effectiveness of air quality management within the class I area of great smoky mountains national park. Environ Manage 1995;19(4):515-26.

64. Schilling JS, Lehman ME. Bioindication of atmospheric heavy metal deposition in the Southeastern US using the moss Thuidium delicatulum. Atmos Environ 2002;36(10):S1611-8.

65. Edwards P, Huber C, Wood F. Ozone exposures and implications for vegetation in rural areas of the central Appalachian mountains, USA. Environ Monit Assess 2004;98(1-3):157-74.

66. Thomas RB, Spal SE, Smith KR, Nippert JB. Evidence of recovery of Juniperus virginiana trees from sulfur pollution after the clean air act. Proc Natl Acad Sci USA 2013;110(38):15319-24.

67. Boylan JW, Odmana MT, Wilkinsona JG, Russella AG, Doty KG, et al. Development of a comprehensive, multiscale 'one-atmosphere' modeling system: application to the Southern Appalachian mountains. Atmos Environ 2002;36(23):3721-34.

68. Boylan JW, Odman MT, Wilkinson JG, Russell AG, KG Doty, et al. Integrated assessment modeling of atmospheric pollutants in the Southern Appalachian Mountains. Part I: Hourly and seasonal ozone. J Air Waste Manage Assoc 2005;55(7):1019-30.

69. Boylan JW, Odman MT, Wilkinson JG, Russell AG. Integrated assessment modeling of atmospheric pollutants in the Southern Appalachian Mountains: Part II. Fine particulate matter and visibility. J Air Waste Manage Assoc 2006;56(1):12-22.

70. Brewer PF, Adlhoch JP. Trends in speciated fine particulate matter and visibility across monitoring networks in the southeastern United States. J Air Waste Manage Assoc 2005;55(11):1663-74.

71. Li Y, Gibson JM. Health and air quality benefits of policies to reduce coal-fired power plant emissions: a case study in North Carolina. Environ Sci Technol 2014;48(17):10019-27.

72. Nichols CE, Baseler WA, Thapa D, LaFata G, Croston TL, et al. Mountain-top mining particulate matter exposure increases markers of mitochondrially-driven apoptosis in rat cardiac tissue. FASEB J 2012;26:1036.15.

73. Knuckles TL, Stapleton PA, Minarchick VC, Esch L, McCawley M, et al. Air pollution particulate matter collected from an Appalachian mountaintop mining site induces microvascular dysfunction. Microcirculation 2013;20(2):158-69.

74. Luanpitpong S, Chen M, Knuckles T, Wen S, Luo J, et al. Appalachian mountaintop mining particulate matter induces neoplastic transformation of human bronchial epithelial cells and promotes tumor formation. Environ Sci Technol 2014;48(21):12912-9.

75. Baumgardner RE, Edgerton ES. Rural ozone across the eastern United States: analysis of CASTNet data, 1988-1995. J Air Waste Manage Assoc 1998;48(8):674-88.

76. Lampe DJ, Stolz JF. Current perspectives on unconventional shale gas extraction in the Appalachian basin. J Environ Sci Heal A Tox Hazard Subst Environ Eng 2015;50(5):434-46.

77. Kim SG, Cho S-H, Lambert DM, Roberts RK. Measuring the value of air quality: application of the spatial hedonic model. Air Qual Atmos Heal 2010;3(1):41-51.

78. Robson M, Schneider D. Environmental health issues in rural communities. Environ Heal 2001;63(10):16-9.
79. McSpirit S, Reid C. Residents' perceptions of tap water and decisions to purchase bottled water: a survey analysis from the Appalachian, big sandy coal mining region of West Virginia. Soc Nat Resour An Int J 2011;24(5):511-20.

80. Blakeney A, Marshall A. Water quality, health, and human occupations. Am J Occup Ther 2009;63:46-57.

81. ARC. Appalachian Regional Commission: Community Infrastructure, 2016. [Online]. Available at: http://www.arc.gov/ infrastructure.

82. USEPA. Private Drinking Water Wells, 2016. [Online]. Available at: https://www.epa.gov/privatewells.

83. Smith T, Krometis LA, Hagedorn C, Lawrence AH, Benham B, et al. Associations between fecal indicator bacteria prevalence and demographic data in private water supplies in Virginia. J Water Health 2014;12(4):824.

84. Palmer MA, Bernhardt ES, Schlesinger WH, Eshleman KN, Foufoula-Georgiou E, et al. Mountaintop mining consequences. Science 2011;327:148-9.

85. Cañedo-Argüelles M, Hawkins CP, Kefford BJ, Schäfer RB, Dyack BJ, et al. Saving freshwater from salts. Science 2016;351(6276):914-6.

86. Ty Lindberg T, Bernhard ES, Bier R, Helton AM, Brittany Merola R, et al. Cumulative impacts of mountaintop mining on an Appalachian watershed. PNAS 2011;108(52):20929-34.

87. Hitt NP, Hendryx M. Ecological integrity of streams linked to human cancer mortality rates. Ecohealth 2010;7(1):91-104.

88. Wigginton A, McSpirit S, Sims CD. Heavy metal accumulation in hot water tanks in a region experiencing coal waste pollution and comparison between regional water systems. Bull Environ Contam Toxicol 2007;79(4):405-9.

89. Shiber JG. Arsenic in domestic well water and health in central Appalachia, USA. Water Air Soil Pollut 2005;160(1):327-41.

90. Pieper K, Krometis L, Benham B, Gallagher D. Simultaneous influence of geology and system design on drinking water quality in private systems. J Environ Health 2016;79:E1-9.

91. Gasteyer S, Vaswani R. Still living without the basics in the 21st century: analyzing the availability of water and sanitation services in the United States. Rural Community Assist Proj 2004. [Online]. Available: http://opportunitylinkmt.org/wp-content/ uploads/2015/07/Still-Living-Without-the-Basics-Water.pdf.

92. Cook N, Sarver E, Krometis L-A. Putting corporate social responsibility to work in mining communities: exploring community needs for central appalachian wastewater treatment. Resources 2015;4(2):185-202.

93. Banks A, Jones A, Blakeney A. Headwaters: a student/faculty participatory research project in an eastern Kentucky community. J Appalach Stud 2005;11:104-32.

94. Glasmeier AK, Farrigan TL. Poverty, sustainability, and the culture of despair: can sustainable development strategies support poverty alleviation in America's most environmentally challenged communities? Ann Am Acad Pol Soc Sci 2003;590:131-48.

95. Wallender EK, Ailes EC, Yoder JS, Roberts VA, Brunkard JM. Contributing factors to disease outbreaks associated with untreated groundwater. Ground Water 2014;52(6):886-97.

96. HBS. Highlands Biological Station Homepage, 2016. [Online]. Available at: http://highlandsbiological.org/station/.

97. NatureConservancy. Southern Appalachian Mountains, 2016.

98. Alawattegama SK, Kondratyuk T, Krynock R, Bricker M, Rutter JK, et al. Toxic/hazardous substances and environmental 
engineering well water contamination in a rural community in southwestern Pennsylvania near unconventional shale gas extraction well water contamination in a rural community in southwestern Pennsylvania near unconventional shale gas extraction," 4529, no. April 2017, 2015.

99. Mitka M. Rigorous evidence slim for determining health risks from natural gas fracking. J Am Med Assoc 2012;307(20):2135-6.

100. Rasmussen S, Ogburn EL, McCormack M, Casey JA, BandeenRoche K, et al. Association between unconventional natural gas development in the Marcellus Shale and Asthma exacerbations. JAMA Intern Med 2016;176(9):1334-43.

101. Tustin AW, Hirsch AG, Rasmussen SG, Casey JA, Bandeen-roche $\mathrm{K}$, et al. Associations between unconventional natural gas development and nasal and sinus, migraine headache, and fatigue symptoms in Pennsylvania. Environ Health Perspect 2017;125(2):189-97.

102. Jemielita T, Gerton GL, Neidell M, Chillrud S, Yan B, et al. Unconventional gas and oil drilling is associated with increased hospital utilization rates. PLoS One 2015;10(8):e0137371.

103. Sangaramoorthy T, Jamison AM, Boyle MD, Payne-Sturges DC, Sapkota A, et al. Social science \& medicine place-based perceptions of the impacts of fracking along the Marcellus Shale. Soc Sci Med 2016;151:27-37.

104. Mckenzie LM, Guo R, Witter RZ, Savitz DA, Newman LS, et al. Birth outcomes and maternal residential proximity to natural gas development in rural Colorado. Environ Health Perspect 2014;(4):412-7.

105. Stacy SL, Brink LL, Larkin JC, Sadovsky Y, Goldstein BD, et al. Perinatal outcomes and unconventional natural gas operations in Southwest Pennsylvania. PLoS One 2015;10(6):e0126425.

106. Resick LK, Knestrick JM, Counts MM, Pizzuto LK. The meaning of health among mid-Appalachian women within the context of the environment. J Environ Stud Sci 2013;3(3):290-6.

107. Townsend PA, Helmers DP, Kingdon CC, McNeil BE, de Beurs $K M$, et al. Changes in the extent of surface mining and reclamation in the Central Appalachians detected using a 1976-2006 landsat time series. Remote Sens Environ 2009;113(1):62-72.

108. Wickham JD, Riitters KH, Wade TG, Coan M, Homer C. The effect of Appalachian mountaintop mining on interior forest. Landsc Ecol 2007;22(2):179-87.

109. Drummond MA, Loveland TR. Land-use pressure and a transition to forest-cover loss in the eastern United States. Bioscience 2010;60(4):286-98.
110. Cordial P, Riding-Malon R, Lips H. The effects of mountaintop removal coal mining on mental health, well-being, and community health in Central Appalachia. Ecopsychology 2012;4(3):201-8.

111. Zhang Z, Infante A, Meit M, English N, Dunn M, et al. An analysis of mental health and substance abuse disparities \& access to treatment services in the Appalachian region. Appalachian Regional Commission 2008. [Online]. Available at: http:// www.arc.gov/research/researchreportdetails.asp?REPORT_ $\mathrm{ID}=71$.

112. Zullig KJ, Hendryx M. Health-related quality of life among central appalachian residents in mountaintop mining counties. Am J Public Health 2011;101(5):848-53.

113. Albrecht G. Chronic environmental change: emerging. 'Psychoterratic' syndromes. In: Climate change and human well-being. New York, NY, USA: Springer, 2011:43-56.

114. Wallack L, Lawrence R. Talking about public health: developing america's second language. Am J Public Health 2005;95(4):567-70.

115. Minkler M. Community organizing and community building for health and welfare, 3rd ed. Brunswick, NJ: Rutgers University Press, 2012.

116. Hutson SP, Dorgan KA, Phillips AN, Behringer B. The mountains hold things in: the use of community research review work groups to address cancer disparities in Appalachia. Oncol Nurs Forum 2007;34(6):1133-9.

117. Schoenberg NE, Howell BM, Fields N. Community strategies to address cancer disparities in Appalachian Kentucky. Fam Community Heal 2012;35(1):31-43.

118. Bencivenga M, DeRubis S, Leach P, Lotito L, Shoemaker C, et al. Community partnerships, food pantries, and an evidencebased intervention to increase mammography among rural women. J Rural Heal 2008;24(1):91-5.

119. Schetzina K, Dalton W, Pfortmiller D, Robinson H, Lowe E, et al. The winning with wellness pilot project: rural Appalachian elementary student physical activity and eating behaviors and program implementation 4 years later. Fam Community Heal 2011;34(2):154-62.

120. Behringer B, Friedell GH. Appalachia: where place matters in health. Prev Chronic Dis 2006;3(4):A113.

121. Cooper C, Knotts G, Livingston D. Appalachian identity and policy opinions. J Appalach Stud 2010;16(1/2):26-41.

122. Morse C, Mudgett J. Longing for landscape: homesickness and place attachment among rural out-migrants in the 19th and 21st centuries. J Rural Stud 2017;50:95-103. 
Reproduced with permission of copyright owner. Further reproduction prohibited without permission. 